\title{
Performance of an Intelligent Biomass Fuel Burner as an Alternative to Coal-Fired Heating for Tobacco Curing
}

\author{
Fan He ${ }^{1 \#}$, Fengjie Wei ${ }^{2 \#}$, Caijuan Ma ${ }^{3 \#}$, Haobin Zhao ${ }^{2}$, Yikuan Fan ${ }^{2}$, \\ Longfei Wang ${ }^{3}$, Jian-An Wang ${ }^{1 *}$ \\ ${ }^{1}$ College of Tobacco Science, Henan Agricultural University, Zhengzhou, Henan 450002, China \\ ${ }^{2}$ China National Tobacco Corporation Henan Provincial Company, Zhengzhou, Henan 450046, China \\ ${ }^{3}$ Xuchang Tobacco Company, Xuchang, Henan 461000, China
}

Received: 12 February 2020

Accepted: 7 May 2020

\begin{abstract}
As an alternative to fossil fuels, biomass burning represents a feasible way of greening the tobacco flue-curing-drying process, especially when it is self-produced. In this work, a biomass briquette fuel (BBF) burner used for flue-curing tobacco was designed and assembled using modern and mature electromechanical technologies, while also making use of its own structure to prevent high-temperature damage to the photoelectric elements during fuel combustion, and deploying an intelligent tobacco controller (ITC) to ensure orderly heating. A comparison between this new burner and a traditional coal-fired heating furnace revealed that when ITC was in operation, the BBF could meet the heating needs for tobacco curing, and the temperature difference between the target and the actual dry-bulb temperature (DBT) in the bulk curing barn was well controlled within a range of $\pm 0.5^{\circ} \mathrm{C}$. Additionally, the BBF burner fully used the biomass briquette and reduced the cost per kilogram of dry leaf curing. Furthermore, non-manual management heating modes could be realized during firing. Considering that the structure of the new device is similar to gas or oil burners, in terms of heating via connecting sockets, it can also potentially be used in small-scale boilers if the ITC programming chip is changed.
\end{abstract}

Keywords: biomass pellet, drying device, solid fuel combustor, Virginia tobacco, intelligent control

\section{Introduction}

In recent years, excessive carbon dioxide $\left(\mathrm{CO}_{2}\right)$ emissions have already led to a series of environmental problems. As the largest flue-cured/Virginia tobacco

\#Authors contributed equally to this paper. *e-mail:wangja@henau.edu.cn
(Nicotiana tobacum L.) producer in the world, China currently grows about one-third of the world's tobacco annually [1], and tobacco curing (TC) is the most energy-intensive phase of tobacco production [2]. Traditionally, coal is used to directly burn and heat fluecured tobacco in a bulk curing barn [3, 4]. During the annual TC season, millions of tons of $\mathrm{CO}_{2}$ and fly dust are emitted into the atmosphere from the chimneys, which causes serious environmental pollution $[5,6]$; 
therefore, this mode of tobacco production is extremely unpopular [7]. However, as a cash crop, flue-cured tobacco is indispensable for the income of farmers in remote areas, and its cultivation cannot be prohibited $[8,9]$. Therefore, in recent years, increasing government attention has focused on the problem of flue-cured tobacco pollution [10,11], and tobacco planters have begun to use cleaner energy sources, such as biomass, alcohol-based liquid fuel, and heat pumps to provide heat for TC [12-14].

As an important type of clean energy, biomass fuel has been used in many countries that grow flue-cured tobacco $[15,16]$, and through an analysis of existing literature and data, some researchers have agreed that the use of biomass energy is a feasible way of curing tobacco without employing fossil fuels, thereby allowing for the "greening" of the tobacco flue-curing process [17]. In the past, the most primitive form of biomass fuel involved the direct burning of agricultural straw for flue-cured tobacco heating; however, this has not been continuously promoted due to the high labor costs involved [18]. At present, the main forms of heat supplies using biomass fuel in the flue-curing of tobacco are firewood and biomass briquette fuel (BBF) $[19,20]$. However, the use of firewood for TC involves direct burning of large pieces of wood in a furnace, that has a very low energy efficiency [21]. In addition, the large number of trees felled to provide heating for TC is deforestation and unsustainable [22-24]. The production of $\mathrm{BBF}$ and associated industrial heating technologies are quite mature and are commonly employed in the fields of boiler combustion and industrial power generation in the past ten years [25]. However, the TC heating is quite unique, and mature BBF heating technologies used in other industries cannot be directly transferred for use in TC. Some tobacco processors place BBFs directly into coal-fired furnaces to provide heating for $\mathrm{TC}$; not only is the resulting combustion efficiency low but the amount of tar produced readily blocks flue pipes [3].

According to the combustion/gasification characteristics of BBFs, some researchers have studied the use of special tobacco heating dissipation equipment. For example, Wang et al [26] designed a heating furnace for TC, which greatly improves the combustion efficiency of BBFs. However, the labor costs involved in controlling its operation remain high, and further studies based on the use of modern and mature electromechanical technologies are required. Therefore, this paper presents the design of a new BBF burner for TC heating that is based on the structural characteristics of a gas and liquid fuel combustor, and an intelligent tobacco controller (ITC) is also introduced to reduce operational costs.

\section{Materials and Methods}

\section{Equipment Design and Construction}

Figs 1 and 2 show the structure of the new BBF burner and interior furnace developed in this study, respectively. The new device has four systems: a fuel

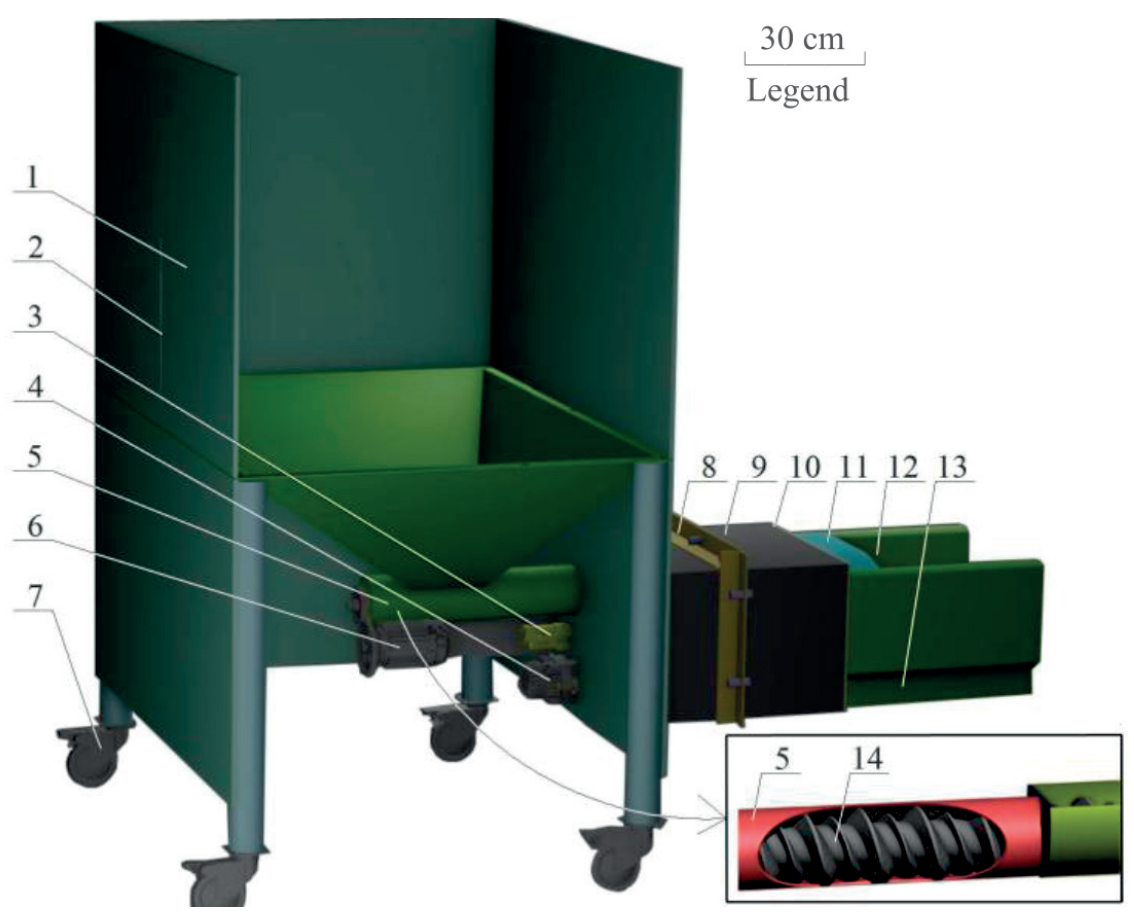

Fig. 1. Structure of the BBF burner: 1. charging bucket, 2. viewing window for fuel, 3. ignition motor, 4. ash-managing motor, 5. round fuel-feeding channel, 6. fuel-feeding motor, 7. universal moving wheel, 8. furnace-sealing interface, 9. ventilation chamber, 10. inner sealing plate, 11. furnace cap, 12. furnace, 13. furnace base, and 14. auger screw conveyor. 


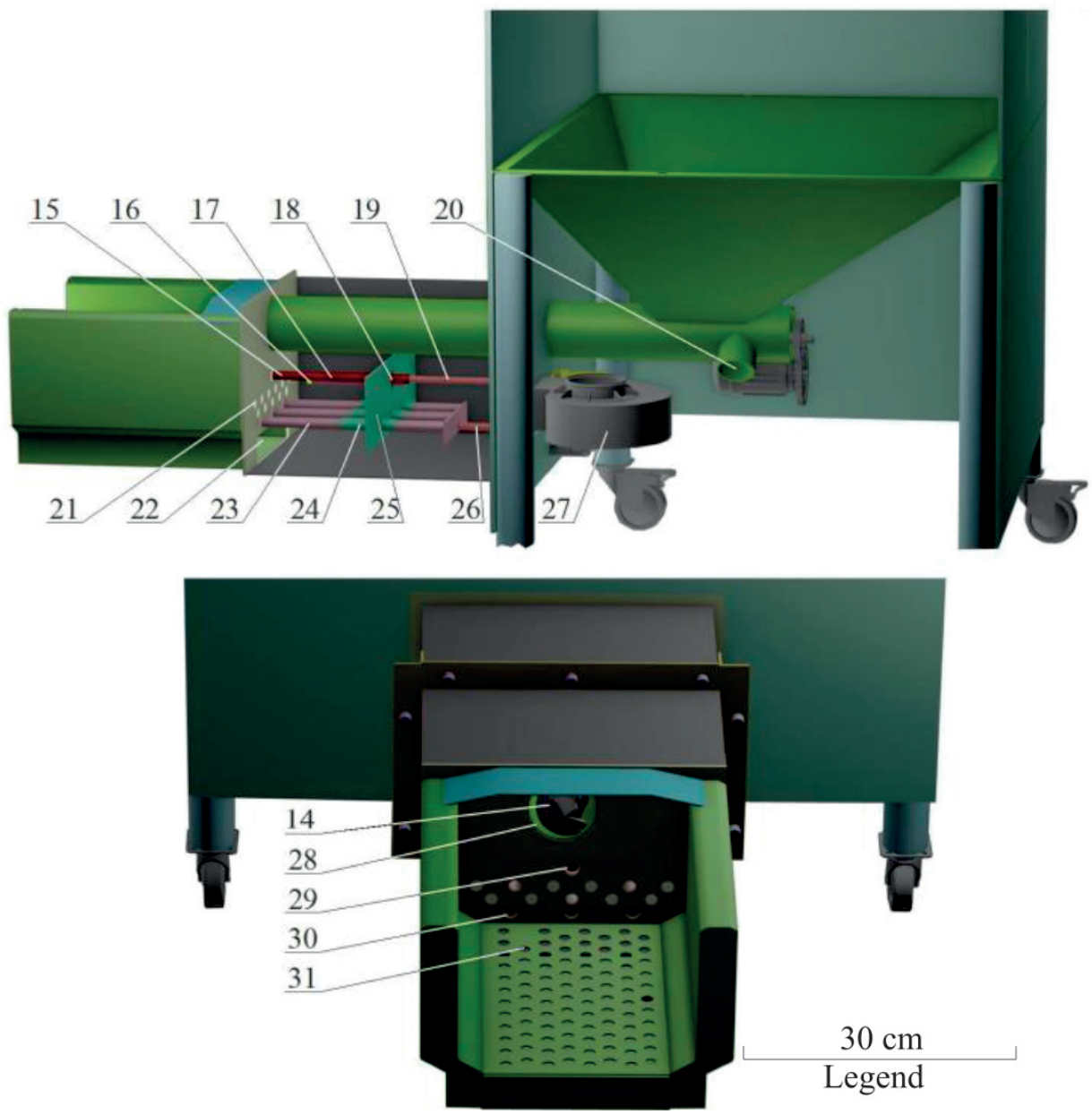

Fig. 2. Interior and furnace outline of the BBF burner: 15. ignition device, 16. infrared detector, 17. convex track, 18. clamping slot, 19. screwdriver rod, 20. maintenance port for fuel, 21. vertical air outlet, 22. ventilation channel, 23. poker, 24. transmission sleeve, 25. retention plate, 26. power transmission device, 27. blower, 27. outlet for fuel, 28. outlet for ignition rod, 29. outlet for poker, and 30. horizontal air outlet.

supply, ventilation-combustion support, ignition, and ash removal systems. The length, width, and height of the device is $1700 \times 800 \times 1400 \mathrm{~mm}$ and the maximum heat supply per hour is $20,000-200,000 \mathrm{~kJ}$.

At the start of $\mathrm{TC}$, the fuel-feeding motor (6) in the fuel supply system sends BBFs from the charging bucket (1) to the furnace (12) through a round fuelfeeding channel (5) via an auger screw conveyor (14). The ignition motor (3) then began to work, passing the screwdriver rod (19) through the clamping slot (18) along a convex track (17) on the retention plate (25), and then through the outlet for the ignition rod (28) on the inner sealing plate (10), to insert the ignition device (15) into the piles of BBF in the furnace (12) and igniting them. Simultaneously, the blower (27) operates to supply oxygen for fuel combustion. The combustionsupporting air blown by the blower (27) depends upon the pressure in the closed ventilation chamber (9). In a horizontal direction, the air is sent out from the horizontal air outlet (30) through the ventilation channel (22) of the furnace base (13) to provide $\mathrm{O}_{2}$ for combustion; and in a vertical direction, the air is sent out from the vertical air outlet (21) for BBF gasification and gas combustion. The advantage of this ventilation structure is that the fire setting, ignition device, and round fuel-feeding channel in the ventilation chamber (9) are close to one side of the furnace-sealing interface (8), which thus avoids any damage occurring from the high temperatures. An infrared detector (16) is installed in the front of the convex track (17). After fuel combustion has been detected, the ignition motor (3) control the return rotation of the screwdriver rod (19) and shrink the ignition device (15) back to the original position.

As the fuel continues to burn during the TC process, ash accumulates in the furnace (12), and the ash-managing motor (4) switches on in relation to the number of feeding cycles conducted by the fuel-feeding motor (6). To expand the area of the ash pile, a poker (23) is inserted into the BBF ash pile in the furnace (12) through the path of the power transmission device (26), the transmission sleeve (24) (fixed in the retention plate (25)), and the outlet for the poker (30). At the same time, the vertical and horizontal winds assist in blowing ash away from the furnace (12) and ash removal is achieved. 
In the process of $\mathrm{TC}$, there are dynamic changes in the amount of heat and feeding fuel required, and the speed of the auger screw conveyor (14) driven by the fuel-feeding motor (6) can be altered to deliver such changes. In addition, to ensure a scientifically air pressure and volume, the gear-rotation speeds of the blower (27) to match those of the fuel-feeding motor (6) are controlled by the ITC (microcomputer control).

\section{Working Principle}

The working principle of the curing control system based on the ITC is shown in Fig. 3. Under the control of ITC for TC, combustion is executed according to a preset curing process. To facilitate TC operation, a remote monitoring system is installed on the ITC, by which the curers can ensure remote detection and control over the dry-bulb temperature (DBT) and wetbulb temperature (WBT) through the APP software on their mobile phone.

At the beginning of $\mathrm{TC}$, the curer turns on the ITC, and the ITC immediately begins detecting the actual DBT through the DBT and WBT sensors in the loading chamber of the bulk curing barn. Then, the curer sets the specific values of the target DBT, WBT, and the heating speed on the ITC using the keys. After calculating the existing temperature difference between the target DBT setting and the actual DBT. The ITC governs the speed of the feeding motor of the fuel supply system to transport BBF into the furnace according to this difference, and the blower speed of the ventilation-combustion support system is synchronously matched. At the same time, the infrared detector detects in the new BBF burner that there is no flame in the burner and feeds this information back to ITC, which manages the ignition system that extends into
$\mathrm{BBF}$ in the furnace and conveys electrical power to the ignition rod, in which the heating wire ignites BBF. The infrared detector detects when fuel burns and feeds this information back to ITC, which draws the ignition device back to the original position. Then, during the TC process, the ITC calculates the difference between the target DBT setting and the actual DBT every five seconds and continues to reregulate the fuel supply and ventilation-combustion systems. In the same way, the WBT is controlled by the dehumidification system in ITC.

During the different stages of TC process, the curers observe the status of the leaves to achieve a certain DBT requirements needed to adjust and reset the new value of the target DBT and keeping time by the keys on the ITC. According to the difference between the target DBT setting and the actual DBT. The ITC adjusts the BBF quantity of the fuel supply system and the oxygen volume of the ventilation-combustion system in the unit time.

If the fire in the furnace is extinguished during TC process, it will be detected by the infrared detector, and the feedback into the ITC will start the ignition system again. According to the different raw materials of biomass fuel, the working time of the ash cleaning system can be set using the ITC, which automatically records the number of turns of the screw transmission rod in the fuel supply system and controls the frequency and magnitude of the pokers in BBF reactor.

\section{Heat Calculation}

The DBTs and WBTs of tobacco leaves in a bulk curing barn at different time points are seamlessly connected to form a curing curve during the TC process. This curve has previously been divided into

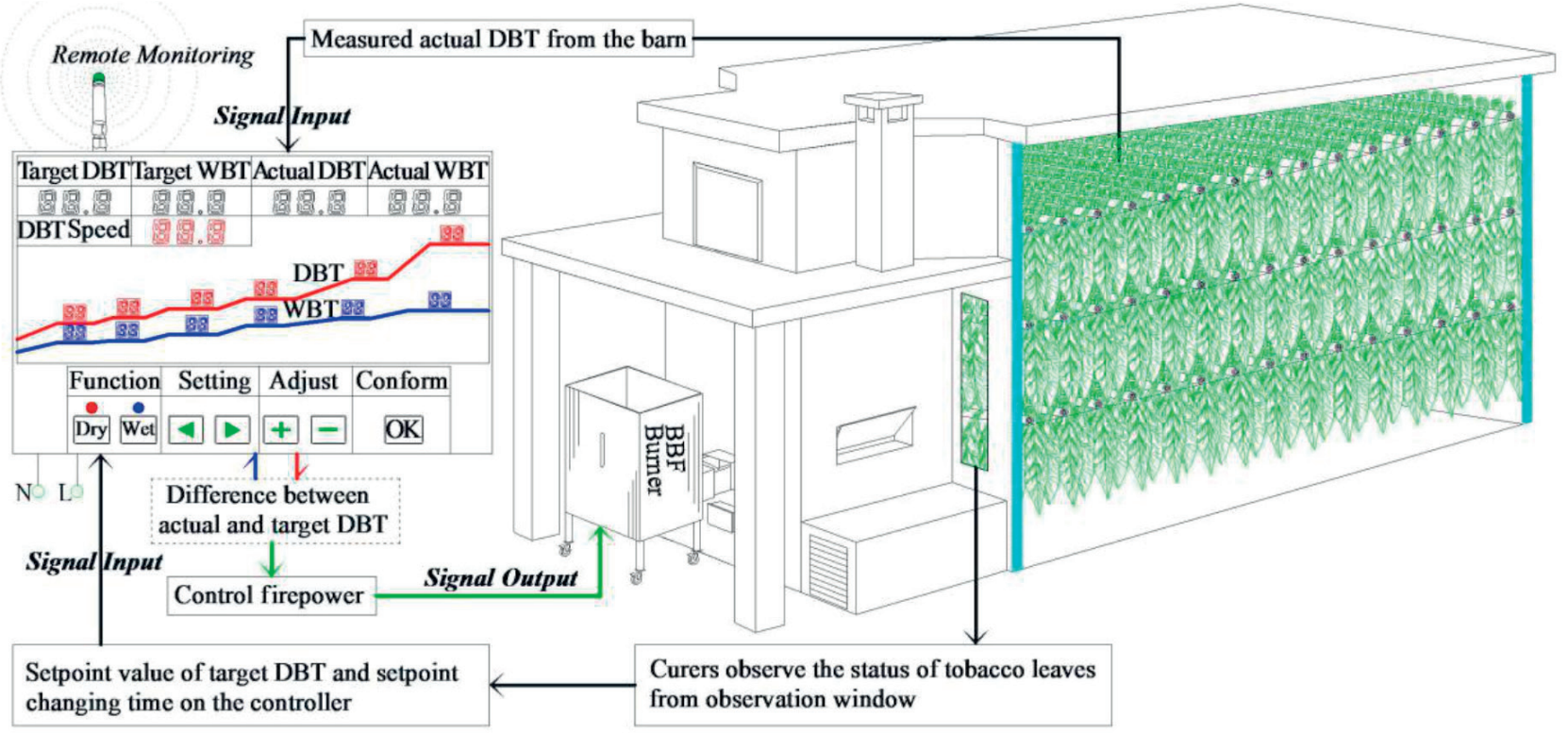

Fig. 3. Flowchart of the control operation diagram based on ITC. 
Table 1. Heat demand and control during tobacco curing process.

\begin{tabular}{|c|c|c|c|c|c|c|}
\hline Stages & $\begin{array}{c}\text { DBT } \\
\left({ }^{\circ} \mathrm{C}\right)\end{array}$ & $\begin{array}{c}\text { DBT speed } \\
\left({ }^{\circ} \mathrm{C} / \mathrm{h}\right)\end{array}$ & $\begin{array}{c}\text { Curing } \\
\text { time }(\mathrm{h})\end{array}$ & Curing index & $\begin{array}{c}\text { Water loss weight } \\
(\mathrm{kg})\end{array}$ & $\begin{array}{c}\text { Water loss } \\
\text { ratio }(\%)\end{array}$ \\
\hline \multirow{2}{*}{$\begin{array}{c}\text { Leaf } \\
\text { Yellow- } \\
\text { ing }\end{array}$} & $\sim 35$ & 1.0 & $5-6$ & Leaf preheating. & $0-220$ & $5<$ \\
\cline { 2 - 8 } & $35 \sim 38$ & 0.5 & $24-36$ & Yellowing of leaf tip and margin & $600-800$ & $14-19$ \\
\hline \multirow{2}{*}{$\begin{array}{c}\text { Leaf } \\
\text { drying }\end{array}$} & $42 \sim 42$ & 0.5 & $24-36$ & Yellowing of leaf center, leaves become soft & $800-900$ & $19-21$ \\
\cline { 2 - 8 } & $46 \sim 54$ & 0.3 & $24-36$ & Whitening of the main vein, leaf drying & $1300-1500$ & $21-26$ \\
\hline $\begin{array}{c}\text { Stem } \\
\text { drying }\end{array}$ & $54-68$ & 1 & $36-48$ & $\begin{array}{c}\text { Partial whitening of the main vein, leaf tip } \\
\text { upside down hook }\end{array}$ & $900-1100$ & $30-35$ \\
\hline
\end{tabular}

three stages by researchers [27], and each stage has an associated dry-bulb temperature (DBT) and amount of time required to initiate water loss in China's tobacco areas, as shown in Table 1. The maximum heat required during the $\mathrm{TC}$ process is $46-54^{\circ} \mathrm{C}$ in the leaf drying stage.

The BBF combustion generates heat energy, thereby heating the steel flue pipe, which heats the air in the heating chamber of the barn; a circulating fan blows the heated air into the loading chamber of the barn, where high-low temperature circulation between the loading chamber and heating chamber occurs, which promotes the yellowing of tobacco in the loading chamber and the timely evaporation of excess water.

The maximum heat demand per unit time per batch per bulk curing bulk barn in the curing barn is $Q_{l}(\mathrm{~kJ} / \mathrm{s})$; this is calculated as:

$$
Q_{1}=\left(m_{f}-m_{d}\right) \bullet c_{w} \cdot \mathrm{P}_{\mathrm{w}} / \eta
$$

...where $m_{f}$ is the loaded fresh tobacco weight per batch in each barn $(\mathrm{kg}) ; m_{d}$ is the loaded dry tobacco weight per batch in each barn $(\mathrm{kg}) ; c_{w}$ is the average heat of the water vaporized from tobacco leaves during curing $(\mathrm{kJ} / \mathrm{Kg}) ; P_{w}$ is the maximum moisture discharge of tobacco leaves per unit time (\%); and $\eta$ is the system thermal efficiency of the bulk curing barn (\%). The heat provided by fuel combustion not only meets the effective heating needs of TC, but also dissipates unnecessary heat to the outside through the wall and roof of the curing barn.

The maximum amount of fuel required to cure tobacco leaves per unit time in a barn is $m_{b}(\mathrm{~kg} / \mathrm{s})$,

$$
\mathrm{m}_{b}=Q_{1} / G_{b}
$$

...where $G_{b}$ is the calorific value of specific BBFs $(\mathrm{kJ} / \mathrm{kg})$.

Furthermore, the rotation speed of the fuel-feeding motor in the feeding system is $N(\mathrm{r} / \mathrm{s})$,

$$
N=m_{b} / \rho \bullet s \bullet c \bullet \pi\left(r_{s}-r_{p}\right)^{2}
$$

...where $\rho$ is the bulk density of biomass materials (the diameter of biomass particles is generally 8-12 mm and the length is 4-5 times the diameter $\left.\left(\mathrm{kg} / \mathrm{m}^{3}\right)\right) ; s$ is the rotor pitch of the auger screw conveyor $(\mathrm{m}) ; c$ is the inclination angle, which is vertical in this study (and $c=1) ; r_{s}$ is the radius of the spiral plate feeder of the auger screw conveyor (m); and $r_{p}$ is the radius of the axle bearing of the auger screw conveyor $(\mathrm{m})$. To more accurately control the heat supply during TC process, five rotational speeds of $0.2 \mathrm{~N}, 0.4 \mathrm{~N}, 0.6 \mathrm{~N}, 0.8 \mathrm{~N}$, and $\mathrm{N}$ were set.

The theoretical air volume required for complete combustion of $1 \mathrm{~kg}$ of $\mathrm{BBFs}$ is $V_{L}\left(\mathrm{Nm}^{3} / \mathrm{kg}\right)$. The molecular formula of the BBFs used in this study is $\mathrm{C}_{\mathrm{x}} \mathrm{H}_{\mathrm{y}} \mathrm{S}_{\mathrm{z}} \mathrm{O}_{\mathrm{w}} \mathrm{N}_{\mathrm{n}}$. However, the formation of nitrogen oxides was too small; thus, $\mathrm{N}_{\mathrm{n}}$ is considered to be converted into $\mathrm{N}_{2}$ during $\mathrm{BBF}$ combustion, and the subscript values of $x, y, z$, and $w$ are determined with respect to the chemicals detected in different BBFs. The molar volume of gas is $22.4 \mathrm{~L} / \mathrm{mol}$ under standard conditions, and the volume of oxygen accounts for $21 \%$ of dry air, such that:

$$
V_{L}=V_{\mathrm{x}}^{C} \bullet V_{y}^{H} \bullet V_{\mathrm{z}}^{S}-V_{w}^{O}
$$

...where $V_{\mathrm{x}}^{C}, \quad V_{y}^{H}, \quad V_{z}^{S}$, and $V_{w}{ }^{O}$ are the theoretical amounts of air required for the combustion of $\mathrm{C}, \mathrm{H}$, $\mathrm{S}$, and $\mathrm{O}$, respectively, in $1 \mathrm{~kg}$ of biomass fuel with different raw materials $\left(\mathrm{Nm}^{3} / \mathrm{kg}\right)$. The contents of each element in the BBFs are similar to those in peat and lignite. The excess air coefficient, $\alpha$, of the combustor is between 1.3 and 1.4 [28], and by substituting $\alpha$ into Equation 5, the actual air demand, $V_{S}\left(\mathrm{Nm}^{3} / \mathrm{kg}\right)$, can be obtained as:

$$
V_{S}=\alpha \bullet m_{b} \bullet V_{L}
$$


To match the rotational speed of the fuel-feeding motor corresponding to different $Q_{1}$ values in each stage, the rotation speeds of the blower are set to $0.2 \mathrm{Vs}$, $0.4 V_{s}, 0.6 V_{s}, 0.8 V_{s}$, and $V_{s}$.

System thermal efficiency $\eta(\%)$ is also calculated using Equation 6:

$$
\eta=\frac{\left(m_{f}-m_{d}\right) \bullet c_{w}}{M_{1} \bullet Q_{2}} \times 100 \%
$$

...where $c_{w}\left(2.6 \times 10^{3} \mathrm{~kJ} / \mathrm{kg}\right)$ is the average heat of vaporization for a leaf during the normal curing process, which is usually calculated when DBT is $50^{\circ} \mathrm{C}$ [29], and $Q_{2}(\mathrm{~kJ} / \mathrm{kg})$ is the net calorific value of BBF.

\section{Methodology}

The experiment was conducted in Xuchang, Luoyang, and Sanmenxia in Henan Province from July-October of 2019. Tobacco leaves that were almost uniform in appearance were selected. The varieties of Zhongyan 100 flue-cured tobacco when mature harvested in the middle of leaves were bound tobacco leaves with woven poles. The amount of tobacco per pole was 120-140 leaves and the loading of fresh tobacco into each loading chamber was controlled at $5000 \pm 50 \mathrm{~kg}$.

Two bulk curing barns with the same structure were employed for the experiment (black lines in Fig. 4), dimensions more precisely described by Wang et al [30]. The one barn housed the original coal-fired heating equipment and was used to heat tobacco with coal as fuel without the controller managing the fire (black lines in Fig. 4). In the other bulk curing barn with curing control system based on the intelligent tobacco controller, the new BBF burner was inserted into the original coal-fired furnace through the coal feeding port (Fig. 4). The fresh leaves were loaded, and firing began at the same time in each barn. The BBFs were composed of tobacco straw, and the coal was desulfurized coal purchased from Inner Mongolia.

When the DBT in the experimental barns was $48^{\circ} \mathrm{C}$, and the fuel was burning steadily [31], the concentration of flue gas discharged from the chimneys was measured at the central position of the chimney outlet using an automatic gas tester (TW-3200, Tuowei Tech. Inc., China). A high-temperature digital sensor (MF53104F-3950-300L, Dongguan Xingxiang Electronic Technology Co., Ltd, China) was installed in the front (vertical air outlet (21), Fig. 2), the middle (retention plate (25), Fig. 2), and rear (power transmission device (26), Fig. 2) of the ventilation chamber of the BBF equipment to detect temperature changes during $\mathrm{BBF}$ combustion. Through the memory of the ITC, the actual changes in DBT and the target curing curve in the tobacco loading chamber were recorded during the TC process with exactly one data point as recording points every ten minutes. Autodesk 3D-Max 2013 and Autocad 2013 software (Autodesk, Inc., USA) were used in drafting the structure and GraphPad Prism v. 5.0 (GraphPad Software, Inc., USA) was used to analyze the experimental data.

\section{Results and Discussion}

\section{Consistency between the Heat Supply and Heat Demand of TC}

Fig. 5 shows the changes in DBT in the two barns during TC. However, at a certain time, there was a $\pm 0.5^{\circ} \mathrm{C}$ difference between the controlled (target) DBT and the actual DBT curve in the BBF barn, which was less than the $\pm 2^{\circ} \mathrm{C}$ difference in the coal barn. During the entire TC process, the deviation of the actual DBT curve from the target DBT of the BBF barn was less than that of the coal barn, which indicates that the heat

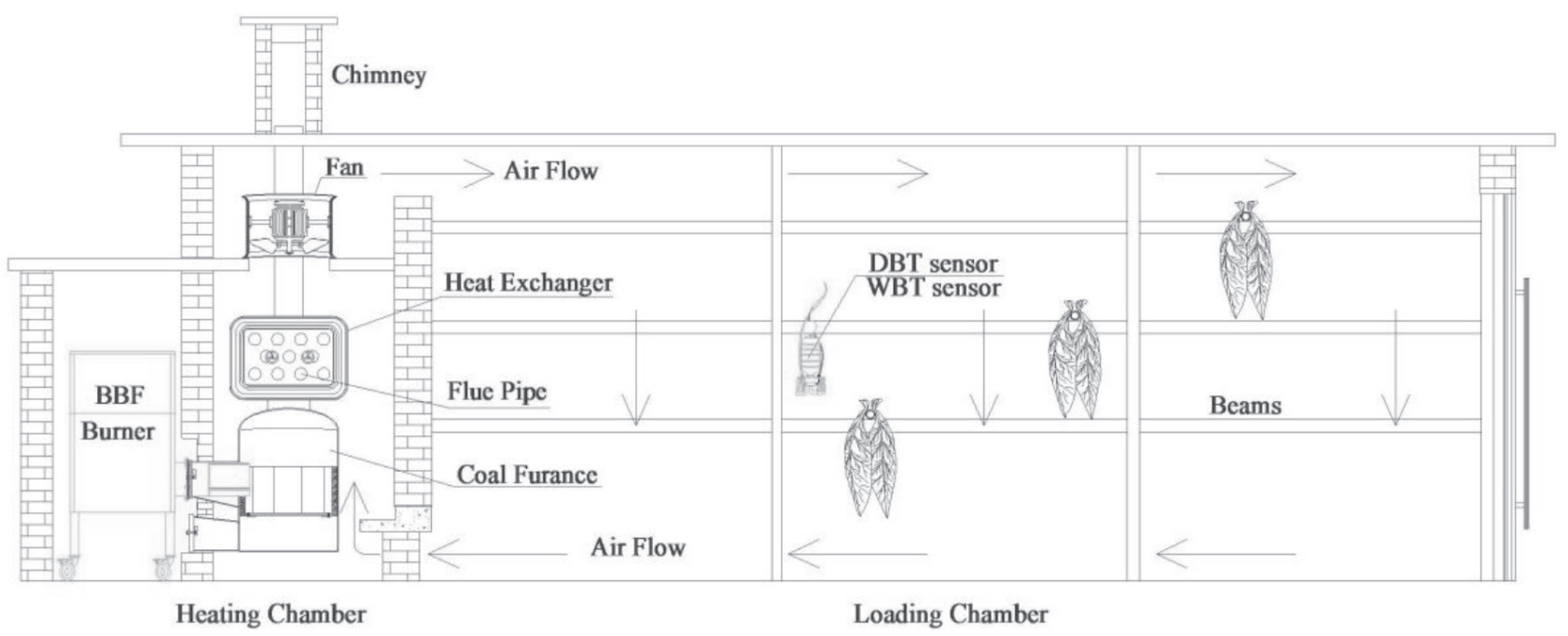

Fig. 4. Internal structure of a bulk curing barn within coal-fired heating equipment after inserted into BBF burner. 


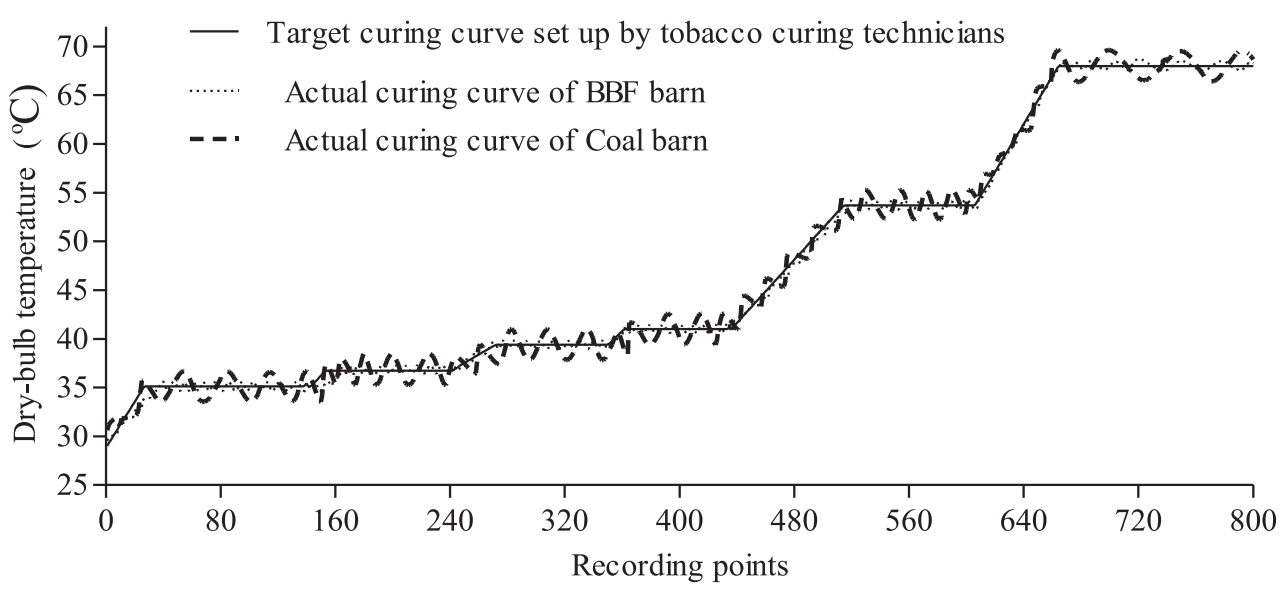

Fig. 5. Actual and target DBT changes during the tobacco curing process.

supply of the BBF barn was better aligned with the heat demand of the tobacco leaves.

\section{Temperature Changes at Different Positions in the Ventilation Chamber during Heating}

To avoid high-temperature damage to the auger screw conveyor in the round feeding channel, a ventilation and cooling structure was designed for the electronic components of the ignition device and the poker device in the ventilation chamber. Fig. 6 shows the temperature changes at the front, middle, and back of the ventilation chamber recorded during the TC process with $\mathrm{BBF}$ stable heating; these temperatures showed a stepwise downward trend, from $350^{\circ} \mathrm{C}$, $145^{\circ} \mathrm{C}$, and $60^{\circ} \mathrm{C}$, respectively. Temperature fluctuations at each detection point were less than $\pm 10^{\circ} \mathrm{C}$. Due to the irregular arrangement of the components in the ventilation chamber, the variability of the curve for he middle detection point was greater than those of the front and rear detection points. In addition, compared with the traditional coal-fired furnace door at $90-105^{\circ} \mathrm{C}$, less heat was lost from the BBF equipment to the outside.

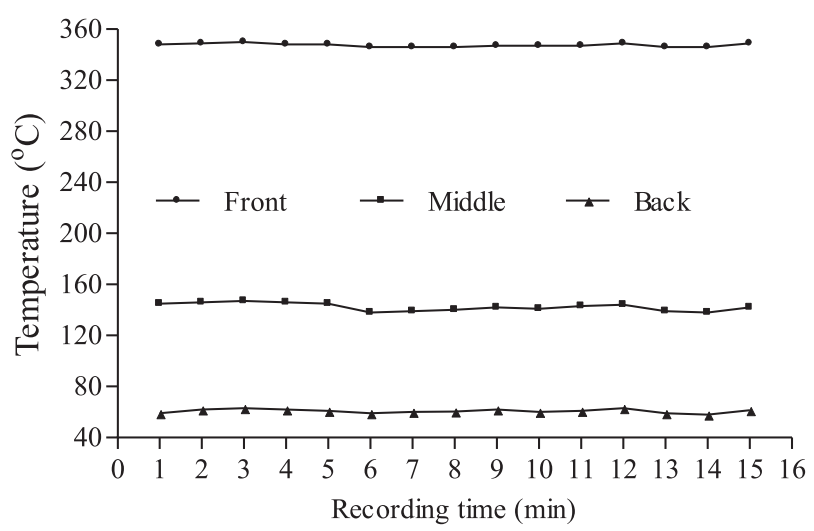

Fig. 6. Temperature changes with time at different positions within the ventilation chamber.

\section{Chimney Emissions}

Table 2 shows the chimney emissions from the two barns to the outside; it is evident that the concentrations of particulate matter, $\mathrm{SO}_{2}$ and $\mathrm{CO}$, from the $\mathrm{BBF}$ barn were significantly less than those from the coal barn. Carbon monoxide is the product of incomplete fuel combustion, and it is clear that combustion in the BBF barn was more efficient than that in the coal barn. The $\mathrm{NO}_{\mathrm{x}}$ concentration was significantly higher than that in the BBF made by tobacco straw. In the future, it will be necessary to combine different biomass materials and increase the catalyst to reduce the $\mathrm{NO}_{\mathrm{x}}$ content in the flue gas.

\section{Comparison between Conventional and Biomass Curing Techniques}

Various factors relating to each barn are quantified in Table 3. Some differences are evident with respect to the costs of fuel, electricity, and the amount of manual labor required in both barns. For example, the use of mature, mechanical, and electrical equipment in the BBF barn does not require the amount of manual labor that is needed in the coal barn to ignite the coal-fired fuel, add fuel frequently, and manage the furnace, which greatly reduces the costs relating to manual operation, and realize an unattended TC mode. In terms of the economic benefit, the operational power consumption of the BBF barn was $0.2 \mathrm{~kW} \cdot \mathrm{h} / \mathrm{h}$, and the power consumption per batch of tobacco was 20-30 $\mathrm{kW} \cdot \mathrm{h}$ higher than that in the coal barn. However, although the fuel consumption of the BBF barn was

Table 2. Detection of chimney tail gas $\left(\mathrm{mg} / \mathrm{m}^{3}\right)$.

\begin{tabular}{|c|c|c|c|c|}
\hline & Particulate emission & $\mathrm{SO}_{2}$ & $\mathrm{NO}_{\mathrm{x}}$ & $\mathrm{CO}$ \\
\hline BBF barn & $88.6 \mathrm{a}$ & $37 \mathrm{a}$ & $230 \mathrm{~b}$ & $214 \mathrm{a}$ \\
\hline Coal barn & $185 \mathrm{~b}$ & $56 \mathrm{~b}$ & $168 \mathrm{a}$ & $247 \mathrm{~b}$ \\
\hline
\end{tabular}


Table 3. Properties of tobacco leaves during curing.

\begin{tabular}{|c|c|c|}
\hline Properties & BBF barn & Coal barn \\
\hline Curing time $(\mathrm{h})$ & 144 & 146 \\
\hline Maximum fuel loading per batch per barn (kg) & $20-$ & 50 \\
\hline Maximum fire keeping time per batch per barn (h) & -- & 6 \\
\hline Green tobacco quality per batch per barn $(\mathrm{kg})$ & 5055 & 5047 \\
\hline Dry tobacco quality per batch per barn (kg) & 643 & 630 \\
\hline Operating cost for labor curing per batch per barn (USD) & 4.28 & 51.41 \\
\hline Fuel consumption per batch per barn $(\mathrm{kg})$ & 1240 & 1309 \\
\hline Power consumption per batch per barn $(\mathrm{kW} \cdot \mathrm{h})$ & 168 & 142 \\
\hline Total cost per barn each batch (USD) & 179.21 & 206.63 \\
\hline Curing cost per kg dry tobacco (USD/kg) & 0.28 & 0.33 \\
\hline System thermal efficiency (\%) & 56.93 & 42.95 \\
\hline
\end{tabular}

Note: "-" is an automatic continuation. Local market prices in 2019 were used to quantify the cost of coal after desulfurization (108.53 USD/t), biomass fuel (128.52 USD/t), and electricity (0.09 USD/kW $\bullet h)$. The calorific value of BBF and coal are $16,250 \mathrm{~kJ} /$ $\mathrm{kg}$ and $20,428 \mathrm{~kJ} / \mathrm{kg}$, respectively.

$30 \mathrm{~kg}$ greater than for the coal barn, the curing cost per kilogram of dry tobacco leaf of the BBF barn was 0.05 USD less than that of the coal barn.

According to biomass history, the curing process for the energy conservation efficiency of TC is a process of gradual improvement. With energy efficiency below $30 \%$, approximately $14 \mathrm{~kg}$ of firewood was consumed to obtain $1 \mathrm{~kg}$ of cured tobacco using direct-fired combustion suggested by Siddiqui and Rajabu [32], and then decreased to around $4.5 \mathrm{~kg} \mathrm{~kg}^{-1}$ of tobacco by Musoni et al [33]. As compared to firewood and the same direct-fired combustion mode, BBF burned more stably mainly due to its uniform size; the upgraded energy efficiency for burning BBF ranged from 39 to $42 \%$ [34]. With burning gasification gas applying the special furnace structure for BBF via manual operation $[26,35]$, the energy efficiency could be improved from 53.17 to $55.26 \%$. In this work, applying mature electromechanical and computer technology with integrated combustion/gasification furnace for BBF, the system thermal efficiency is improved to $56.93 \%$. This shows that the improvement of thermal efficiency of biomass fuel should be based on "uniform fuel size + secondary combustion of gasified gas + precise control of feed" in the process of fuel heating. Energetic density is an important factor affecting the thermal efficiency of flue-cured tobacco [36]. In this work, the diameter and length of the biomass pellets are $10 \mathrm{~mm}$ and $30-50 \mathrm{~mm}$, respectively; thus, it is necessary to use this new $\mathrm{BBF}$ burner to study the thermal efficiencies of the different diameters and lengths of pellets used for heating TC.

The target DBT curve is a standard curve designed by tobacco technological curers according to the conditions of fresh tobacco leaves [37]. An ideal curing process for tobacco leaves is achieved when the actual
DBT controlled in the loading chamber is completely consistent with the target DBT [38]. However, due to the influences of fuel ignition and combustion attenuation, there are typically differences between the actual DBT control and the target DBT. Compared with Xiao [34] and Ren [39] using BBF heating for TC, the difference between the actual and the target $\mathrm{DBT}$ are $\pm 2.8^{\circ} \mathrm{C}$ and $\pm 1.0^{\circ} \mathrm{C}$ respectively; a difference of $\pm 0.5^{\circ} \mathrm{C}$ between them is preferable for the structural design of this new $\mathrm{BBF}$ burner. However, heating intelligent analysis of control program of the complete TC process, variable speed control of auger screw conveyor, wind pressure and speed of blower, and compatibility between them should be further researched in order to improve the accuracy of flue-cured tobacco heating.

The heat supply of the BBF burner used herein was $20,000-200,000 \mathrm{~kJ} / \mathrm{h}$, which makes it appropriate for supplying heat at this scale in agricultural or industrial applications. In recent years, small-scale precision heating with biomass fuel has offered a promising direction for future research [40, 41], and the results of this study highlight the potential for further development that is required to improve efficiency and increase the application of this technology.

\section{Conclusions}

The BBF burner designed and assembled in this study had a fuselage frame, fuel supply, combustion air support, and fire management system. These systems work together during the BBF combustion process to maintain stable fuel combustion and a stable heat supply. The novel design of the ventilation structure effectively reduces damage to the electronic components that can 
be caused by high temperatures. Compared with the traditional coal-fired heating equipment, test results showed that the BBF device met the heating demands of $\mathrm{TC}$, and brought about indirect contact of the operator with smoke and soot.

When the actual DBTs during the TC process rose or fell, thus deviating from the target DBT, the ITC governing the BBF burner increased or decreased the fuel supply to the furnace through its fuel feeding device, thereby maintaining the flame size. The $\mathrm{BBF}$ was thus fully combusted, and the $\mathrm{CO}$ content discharged from the chimney was significantly lower than that from coal-fired heating equipment.

\section{Acknowledgements}

This study was funded by the Henan Provincial Tobacco Company (Grant no. 2018410000270097). We extend our thanks to Tongqing Zhang, Baotong Zhang, and Zhongxin Wu. We also thank Editage [http://www. editage.cn] for their English language editing.

\section{Conflict of Interest}

The authors declare no conflict of interest.

\section{References}

1. WANG X.B., WANG Z., DAI Y., MA K.Y., ZHU L.J., TAN H.Z. Thermogravimetric study on the flue-cured tobacco leaf pyrolysis and combustion using a distributed activation energy model. Asia-Pacific Journal of Chemical Engineering, 12 (1), 75, 2017.

2. LOKER W.M. The rise and fall of flue-cured tobacco in the cop'an valley and its environmental and social consequences. Human Ecology, 33 (3), 229, 2005.

3. WANG J.A., LIU G.S. Development of tobacco-curing system centrally heated by biomass-fueled hot water boiler. Acta Tabacaria Sinica, 18 (6), 32, 2012 [In Chinese with English abstract].

4. PAN L.Y., ZHOU K., LI W.Q., YANG F.Y., LI Z. Subsidy policy discussion on the hydroelectric power substitution for scattered coal consumption: A case study of Sichuan Province. Renewable \& Sustainable Energy Reviews, 108, 539, 2019.

5. GUO Y.L., ZHAO X.H., WANG F., HU D.X., ZHANG D.B., CAO Y. Research on the key technologies of a biomass briquette-fueled curing barn heating system. 2nd International Conference on Energy, Environment and Materials Science (EEMS).; Advances in Energy, Environment and Materials Science: Singapore, Singapore, 105-111, 2017 [In English].

6. HE F., WANG M., WANG T., SUN J.F., HUANG W.X., TIAN B.Q., GONG C.R. Spatial distribution of sulfur dioxide around a tobacco bulk-curing workshop cluster. Chinese Journal of Applied Ecology, 25 (3), 857, 2013 [In Chinese with English abstract].

7. TSIARAS S., SPANOS I. Tree crops cultivation. a sustainable alternative for the development of mountainous, less favoured areas. Journal of Environmental Protection and Ecology, 18 (1), 271, 2017.

8. LU W.C., LATIF A., ULLAH R. Simultaneous adoption of contract farming and off-farm diversification for managing agricultural risks: the case of flue-cured Virginia tobacco in Pakistan. Natural Hazards, 86 (3), 1347, 2017.

9. ZHOU G.S., YIN X.H., LI Y.M., YANG H.W., ZHAO Z.X., CHE P.K., CAO Q.Z., ZHAO H., WANG Y.J., XU L. Effects of relay cropping of corn on the productivity and quality of flue-cured tobacco. Agronomy Journal, 106 (5), 1651, 2014.

10. ZHU W.K., WANG L., DUAN K., CHEN L.Y., LI B. Experimental and numerical investigation of the heat and mass transfer for cut tobacco during two-stage convective drying. Drying Technology, 33 (8), 907, 2015.

11. SHEN D.Y., XIA M.Y., ZHANG Q.Y., ELAHI E., ZHOU Y., ZHANG H.M. The impact of public appeals on the performance of environmental governance in China: a perspective of provincial panel data. Journal of Cleaner Production, 231, 290, 2019.

12. WANG X.F., XU G.Z., ZHANG B.L., JIAO Y.Z., LU H.F., LI B.M. Application of tobacco stems briquetting in tobacco flue-curing in rural area of China. International Journal of Agricultural and Biological Engineering, 8 (6), 84, 2015.

13. WANG J.A., DUAN W.D., SHEN H.T., ZHANG D.C., MIAO X.H., SONG Z.P. Conjoined furnace using alcoholbased liquid fuels as energy for tobacco curing. Journal of Agricultural Science and Technology, 19 (9), 70, 2017 [In Chinese with English abstract].

14. WANG J.A., SONG Z.P., WEI Y.W., YANG G.H. Combination of waste-heat-recovery heat pump and auxiliary solar-energy heat supply priority for tobacco curing. Applied Ecology and Environmental Research, 15 (4), 1871, 2017

15. DE FARIAS J.A., SCHNEIDER P.R., BIALI L.J. Diagnosis of the forests planted in river basin of 'Pardo' river, Rio Grande do Sul state. Ciencia Florestal, 27 (1), 339, 2017.

16. WELTER C.A., DE FARIAS J.A., DA SILVA D.A., RECH R.D., TEIXEIRA D.D., PEDRAZZI C. Consumption and characterization of forestry biomass used in tobacco cure process. Floresta e Ambiente, https://doi.org/10.1590/21798087.043818, 2019.

17. BORTOLINI M., GAMBERI M., MORA C., REGATTIERI A. Greening the tobacco flue-curing process using biomass energy: a feasibility study for the flue-cured Virginia type in Italy. International Journal of Green Energy, 16 (14), 1220, 2019.

18. DASGUPTA D.J., RAO T.D.P., VITHAL P.S.R.V.S., KAPUR P.C. Flue curing of Virginia tobacco by a tubein-basket (TiB) burner using rice husk as fuel and barn insulation. Resources Conservation and Recycling, 5 (1), 47, 1991.

19. ROY M.M., CORSCADDEN K.W. An experimental study of combustion and emissions of biomass briquettes in a domestic wood stove. Applied Energy, 99, 206, 2012.

20. HUSSAIN M., ZAIDI S.M.H., MALIK R.N., SHARMA B.D. Greenhouse gas emissions from production chain of a cigarette manufacturing industry in Pakistan. Environmental Research, 134, 81, 2014.

21. SIDDIQUI K.M. Analysis of a Malakisi barn used for tobacco curing in east and southern Africa. Energy Conversion and Management, 42(4), 483, 2001.

22. CHINANGWA L., GASPARATOS A., SAITO O Forest conservation and the private sector: stakeholder 
perceptions towards payment for ecosystem service schemes in the tobacco and sugarcane sectors in Malawi. Sustainability Science, 12 (5), 727, 2017.

23. ABDALLAH J.M., MBILINYI B., NGAGA Y.N., OK'TING'ATI A. Impact of flue-cured Virginia on miombo woodland: a case of small-scale flue-cured Virginia production in iringa region, Tanzania. Discovery and Innovation, 19, 92, 2007.

24. MUVENGWI J., CHISANGO T., MPAKAIRI K., MBIBA M., WITKOWSKI E.T.F. Structure, composition and regeneration of miombo woodlands within harvested and unharvested areas. Forest Ecology and Management, https://doi.org/10.1016/j.foreco.2019.117792, 2020.

25. AWAN M.B., IQBAL T., YASEEN S., NAWAZ S., ALI C.H. Techno-economic sustainability analysis of biomass fired industrial boiler: biomass evolution as heat and power generation source. IET Renewable Power Generation, 13(4), 650, 2019.

26. WANG J.A., ZHANG Q., WEI Y.W., YANG G.H., WEI F.J. Integrated furnace for combustion/gasification of biomass fuel for tobacco curing. Waste and Biomass Valorization, 10 (7), 2037, 2019.

27. WEI S., TIAN B.Q., JIA H.F., ZHANG H.Y., HE F., SONG Z.P. Investigation on water distribution and state in tobacco leaves with stalks during curing by LF-NMR and MRI. Drying Technology, 36 (12), 1515, 2018.

28. OZKAYMAK M., CEYLAN M.A., OKUTAN H., ATAKUL H., BERRIN ES., COSKUN T., INANC O.CO emission during the combustion of orhaneli lignite coal. World Journal of Engineering, 14 (1), 27, 2017.

29. TIPPAYAWONG N., TANTAKITTI C., THAVORNUN S. Energy and emission based performance of an experimental tobacco bulk-curing barn. Chiang Mai University Journal, 3 (1), 43, 2004.

30. WANG J.A, WEI F.J, DUAN W.D., ZHANG Y.H, FAN Y.K, SONG Z.P. Performance of solar hot-water installations from roof-constructed solar collectors integrated with a central heating supply for tobacco curing. Thermal Science, https://doi.org/10.2298/ TSCI190406072W, 2020.

31. SUMNER P.E., CUNDIFF J.S. Guidelines for temperature, humidity, and air-flow control in tobacco curing. Georgia Agricultural Experiment Station Research Bulletin, 299, $1-18$.
32. SIDDIQUI K.M., RAJABU H. 1996. Energy efficiency in current tobacco-curing practice in Tanzania and its consequences. Energy, 21(2), 141, 1983.

33. MUSONI S., NAZARE R., MANZUNGU E., CHEKENYA B. Redesign of commonly used tobacco curing barns in Zimbabwe for increased energy efficiency. International Journal of Engineering Science \& Technology, 5 (3), 1314, 2013.

34. XIAO X.D., LI C.M., YA P., HE J., HE Y.S., BI X.T. Industrial experiments of biomass briquettes as fuels for bulk curing barns. International Journal of Green Energy, 12 (11), 1061, 2015.

35. SONG Z.P., WEI F.J., SU X.F., WANG Y.J., FAN Y.K., WANG J.A. Application of automatic control furnace for combustion of biomass briquette fuel for tobacco curing. Thermal Science, https://doi.org/10.2298/TSCI191115148S, 2020.

36. DESSBESELL L., DE FARIAS J.A., ROESCH F. Complementing firewood with alternative energy sources in Rio Pardo Watershed, Brazil. Ciencia Rural, 47 (9), https://doi.org/10.1590/0103-8478cr20151216, 2017.

37. WANG L.T., CHENG B., LI Z.Z., LIU T.M., LI J.N. Intelligent tobacco flue-curing method based on leaf texture feature analysis. OPTIK, 150, 117, 2017.

38. CONDORÍ M., ALBESA F., ALTOBELLI F., DURAN G., SORRENTINO C. Image processing for monitoring of the cured tobacco process in a bulk-curing stove. Computers and Electronics in Agriculture, https://oi.org/10.1016/j. compag.2019.105113, 2020.

39. REN T.B., LIU X.J., XU C.S., FENG H.L., CAI X.J., WEI Y.W., L IU G.S. Application of biomass moulding fuel to automatic flue-cured tobacco furnaces efficiency and costeffectiveness. Thermal Science, 23 (5A), 2667, 2019.

40. KEYBONDORIAN E., ZANBOURI H., BEMANI A., HAMULE T. Application of MLP-ANN strategy to predict higher heating value of biomass in terms of proximate analysis. Energy Sources Part A, 39 (22), 2105-, 2017.

41. SAMADI S.H., GHOBADIAN B., NOSRATI M. Prediction of higher heating value of biomass materials based on proximate analysis using gradient boosted regression trees method. Energy Sources Part A, https:// doi.org/10.1080/15567036.2019.1630521, 2019. 